\title{
Construction and Optimization of Educational Technology Course Knowledge Network
}

\author{
Jingxia Liu and Bin Wen
}

\begin{abstract}
Teachers should not only understand the basic knowledge of the course, but also master the overall structural characteristics of the course, grasp the important and difficult point of the course, and optimize the knowledge structure of the course. This paper mainly applies complex network to the analysis of course knowledge structure to construct and optimize the knowledge network of Educational Technology course. Firstly, the textbook and syllabus of Educational Technology course are used as a data source, and the course knowledge network model is constructed. Secondly, the knowledge nodes and their relationships are determined, and the course knowledge network is constructed. Thirdly, by using topological sorting based on directed graph, the course knowledge structure is optimized. And the pre-optimized and optimized course knowledge network are compared and analyzed, it shows the optimized course knowledge structure has superiority. It proves that the optimized course knowledge structure is more hierarchical, sequential and structural, which can highlight the main line of knowledge and clear the learning ideas. Finally, according to the results of comparative analysis of the pre-optimized and optimized course knowledge network, the teaching suggestions are proposed, and it is to realize the aim of optimizing teaching.
\end{abstract}

Index Terms-Course knowledge network, construction and optimization, course knowledge structure, teaching suggestions.

\section{INTRODUCTION}

With the progress and development of national education, course is an important part of school education, and knowledge is an important educational resource. In today's knowledge society, school education should be given priority in development. This is to promote the progress of the national knowledge economy, and to promote the development of national education. In June 2016, the National Education Department issued a notice document of "the 13th Five-Year Plan for Education Informatization" [1]: "During the 13th Five-Year Plan period, it is necessary to deepen the integration information technology and teaching, by improving the quality and efficiency of teaching and promoting the process of education modernization. The course reform should be designed in the era of information technology, and this can play the role of information technology in teaching". This shows that the country is paying more and more attention to teaching reform. By deepening the reform of information technology and teaching, national education will be better developed and improved. At present, although the state has made some teaching reforms, there are still many problems in the course teaching: (1) The

Manuscript received April 9, 2020; revised July 2, 2020

Jingxia Liu and Bin Wen (Corresponding author) are with School of Information Science and Technology, Yunnan Normal University, Kunming, Yunnan, China (e-mail: 179988079@qq.com, ynwenbin@163.com). overall structural characteristics of the course are neglected, and the overall teaching main line and ideas are lacking. In traditional education, the knowledge point in the course is often used as a single learning object. And the learning of knowledge points ignores the relationship between knowledge points. Then the knowledge points are completely "isolated", and the knowledge points learned by students are not systematic and incomplete [2]. (2) The important and difficult points in the course teaching are not prominent, and the teaching content and objectives are not clear. Nowadays, in the analysis of the important and difficult point of the course, some teachers mainly rely on the course itself and existing teaching experience. In addition to using frequency statistical analysis methods, it is difficult to analyze by scientifically quantified analytical method [3]. These problems have seriously affected the quality and efficiency of teaching. And they have become very important research issues in the domestic course reform.

The American Computer Society and the IEEE Computer Society have proposed in the "Computer Systems and Technology" International Conferenc"- the tree diagram of knowledge systems [4]. In this tree diagram, there are mainly four different levels: subjects, courses, knowledge units and knowledge points. In materialist dialectics, it is believed that things are universally connected, and various objective things are interrelated, rather than isolated [5]. So, there are close relationships between these four different levels, and they have an inclusion relationship. Knowledge units and knowledge points form the entire knowledge structure of the subject course. If a knowledge point includes more sub-knowledge points, then the more important this point is. And its importance is closely related to the number of sub-knowledge points [6], thus forming the important content of the course. Because this knowledge point includes many sub-knowledge points, so it has a large relationship complexity, and it is difficult to understand and master. Then this increases the difficulty of learning the knowledge point, and they formed the difficult content of the course. In addition, the Educational Technology discipline is an applied cross-discipline, and it has formed an independent knowledge system. Since there are many knowledge points and various knowledge relationships in the Educational Technology course, and due to certain knowledge relationships, each knowledge point of the course forms the important and difficult point in the teaching process. Here, in order to analyze and study the content of the Educational Technology course, complex network tools are used. This can provide a new approach and perspective, and some researchers have turned from theoretical thinking to the scientific direction of mathematical statistics. And this also makes the research results more convincing [7]. If the 
knowledge points in the Educational Technology course are used as network nodes, and the knowledge relationship is used as the network connection. Then according to certain rules, these knowledge points and knowledge relationships can form a course knowledge network. The course knowledge network is a kind of networked knowledge system. It is composed of the course knowledge points and the relationship between them. This networked knowledge system has a complex topology [8], [9]. If only the text information or statistical data is used to represent the structure of the course knowledge network, it may lead to the lack of many data information, and it is extremely difficult to observe. In this context, it is particularly important to analyze and study the Educational Technology course knowledge network.

For the problems such as the overall knowledge structure of the course, the important and difficult point in the course, etc. By citing the ideas of the course knowledge network and according to the knowledge points of the course and the relationship between them, various related knowledge points are connected, thus forming a complete course knowledge structure system. In this way, the complex network tools can be used to visually display the topology of the course knowledge network, which provides convenience for analyzing the attributes and features of the course knowledge network. By applying complex networks to the analysis of course knowledge structure, then an objective and scientific course knowledge structure analysis method is established. This can help teachers understand the overall structural characteristics of the course, and grasp the important and difficult point of the course. This can also enable students to construct a good overall cognitive structure, and to establish a clear knowledge line and learning ideas. This is also to improve the quality of teachers' teaching and to improve the efficiency of students' learning. This paper mainly constructs the course knowledge network based on the Educational Technology course, and further optimizes the course knowledge structure. Then combined with the actual teaching characteristics, the pre-optimized and optimized course knowledge network are compared and analyzed. Finally, according to the comparative analysis results of the pre-optimized and optimized course knowledge network, the corresponding teaching suggestions are proposed, and this is to realize the purpose of optimizing teaching.

\section{Construction of Educational TeChnology Course KNOWLEDGE NETWORK MODEL}

There are many knowledge points and knowledge relations in the Educational Technology course. In order to facilitate research and analysis, and to establish the topology map of course knowledge network. We can consider the course knowledge structure to be expressed by a network model, thus further forming course knowledge network. If we want to fully display the knowledge points and knowledge relationships in the course, the course knowledge network model can be used to express it. In this way, the knowledge network model that can objectively and comprehensively reflect the course overall structure is constructed.

Here, we define the knowledge structure system (K-System) of the Educational Technology course as a five-tuple: $\mathrm{K}-$ System $=\left(\mathrm{U}, \mathrm{P}, \mathrm{R}_{\mathrm{UU}}, \mathrm{R}_{\mathrm{UP}}, \mathrm{R}_{\mathrm{PP}}\right)$, among them, $\mathrm{U}$ is a collection of course knowledge units, $\mathrm{P}$ is a collection of course knowledge points, $\mathrm{R}_{\mathrm{UU}}$ is a collection of relationships between knowledge units and knowledge units, $R_{U P}$ is a collection of relationships between knowledge units and knowledge points, $R_{P P}$ is a collection of relationships between knowledge points and knowledge points. They are described as follows:

1) U: As the Educational Technology course includes many knowledge units. Therefore, a knowledge unit object can be defined as: $U=\left\{\mathrm{u}_{1}, \mathrm{u}_{2}, \mathrm{u}_{3}, \ldots, \mathrm{u}_{\mathrm{m}}\right\}$. That is, the course is composed of $\mathrm{m}$ knowledge unit objects.

2) P: As the Educational Technology course includes many knowledge points. Therefore, a knowledge point object can be defined as: $\mathrm{P}=\left\{\mathrm{p}_{1}, \mathrm{p}_{2}, \mathrm{p}_{3}, \ldots, \mathrm{p}_{\mathrm{n}}\right\}$. That is, the course is composed of $\mathrm{n}$ knowledge point objects.

3) $\mathrm{R}_{\mathrm{UU}}$ : In the Educational Technology course, we can learn another knowledge unit after learning a knowledge unit. Thence, it is defined that each knowledge unit $U$ has a sequential knowledge relationship. $\mathrm{R}_{\mathrm{UU}}$ can be expressed as an $\mathrm{m} \times \mathrm{m}$ matrix, as shown in formula (1). When $\mathrm{u}_{\mathrm{i}}$ has a relationship with $u_{j}, u_{i} u_{j}=1$, otherwise it is 0 . That is, $R_{U U}$ is a $\mathrm{m} \times \mathrm{m}(0,1)$ matrix.

$$
R_{U U}=\left[\begin{array}{cccc}
u_{1} u_{1} & u_{1} u_{2} & \ldots & u_{1} u_{m} \\
u_{2} u_{1} & u_{2} u_{2} & \ldots & u_{2} u_{m} \\
\ldots & \ldots & \ldots & \ldots \\
u_{m} u_{1} & u_{m} u_{2} & \ldots & u_{m} u_{m}
\end{array}\right]
$$

4) $\mathrm{R}_{\mathrm{UP}}$ : In the Educational Technology course, because a knowledge unit includes many knowledge points, and many knowledge points can form a knowledge unit. Thence, it is defined that each knowledge unit $U$ and each knowledge point $\mathrm{P}$ have a mutual inclusion relationship. $\mathrm{R}_{U P}$ can be expressed as an $m \times n$ matrix, as shown in formula (2). When $\mathrm{u}_{\mathrm{i}}$ has a relationship with $\mathrm{p}_{\mathrm{j}}, \mathrm{u}_{\mathrm{i}} \mathrm{p}_{\mathrm{j}}=1$, otherwise it is 0 . That is, $\mathrm{R}_{\mathrm{UP}}$ is a $\mathrm{m} \times \mathrm{n}(0,1)$ matrix.

$$
R_{U P}=\left[\begin{array}{cccc}
u_{1} p_{1} & u_{1} p_{2} & \ldots & u_{1} p_{n} \\
u_{2} p_{1} & u_{2} p_{2} & \ldots & u_{2} p_{n} \\
\ldots & \ldots & \ldots & \ldots \\
u_{m} p_{1} & u_{m} p_{2} & \ldots & u_{m} p_{n}
\end{array}\right]
$$

5) $\mathrm{R}_{\mathrm{PP}}$ In the Educational Technology course, we can learn another knowledge point after learning a knowledge point. Thence, it is defined that each knowledge point $\mathrm{P}$ has a sequential knowledge relationship. $\mathrm{R}_{\mathrm{PP}}$ can be expressed as an $n \times n$ matrix, as shown in formula (3). When $p_{i}$ has a relationship with $p_{j}, p_{i} p_{j}=1$, otherwise it is 0 . That is, $R_{P P}$ is a $n$ $\times \mathrm{n}(0,1)$ matrix.

$$
R_{P P}=\left[\begin{array}{cccc}
p_{1} p_{1} & p_{1} p_{2} & \cdots & p_{1} p_{n} \\
p_{2} p_{1} & p_{2} p_{2} & \cdots & p_{2} p_{n} \\
\cdots & \cdots & \cdots & \cdots \\
p_{n} p_{1} & p_{n} p_{2} & \cdots & p_{n} p_{n}
\end{array}\right]
$$

The course knowledge network model mentioned here is a mathematical abstraction of the actual course knowledge network. It is a model that describes the relationship between 
the course knowledge network and its internal elements. And this model contains many knowledge nodes and complex knowledge relationships. The information included in the knowledge node of the course knowledge network is not only its own information, but also reflects the influence of the knowledge node on other knowledge nodes in the network. That is, the course knowledge network is a "map" with specific attributes and functions [10]. Then using the complex network analysis theory, according to the five-tuple in the above knowledge structure system, the course knowledge network can be defined as a three-tuple: $\mathrm{G}=(\mathrm{V}, \mathrm{E}, \mathrm{L})$. Where $\mathrm{V}$ represents a collection of knowledge nodes in the course knowledge network, $V=\left\{\mathrm{v}_{1}, \mathrm{v}_{2}, \ldots, \mathrm{v}_{\mathrm{n}}\right\}$ represents $n$ knowledge nodes in the graph. E represents a collection of connected edges between knowledge nodes in the course knowledge network, $E=\left\{\mathrm{e}_{1}, \mathrm{e}_{2}, \ldots, \mathrm{e}_{\mathrm{m}}\right\}$ represents $\mathrm{m}$ edges between the knowledge nodes in the graph. L represents a collection of knowledge nodes and edge update rules, $\mathrm{L}=\left\{1_{1}, \mathrm{l}_{2}, \ldots, \mathrm{l}_{\mathrm{k}}\right\}$ represents the knowledge nodes and edges of the graph with $\mathrm{k}$ kinds of update rules. $\left(\mathrm{v}_{\mathrm{i}}, \mathrm{v}_{\mathrm{j}}\right) \in \mathrm{E}$ indicates that the knowledge node $v_{i}$ and the knowledge node $\mathrm{v}_{\mathrm{j}}$ are related to each other, then there is a connected edges between the knowledge node vi and vj in the graph.

(1) The node set V of the course knowledge network: The knowledge node set is mainly composed of the knowledge unit set $\mathrm{U}$ and the knowledge point set $\mathrm{P}$.

(2) The set E of connected edges between nodes in the course knowledge network: The relationship $\mathrm{R}_{\mathrm{UU}}$ between the knowledge unit and the knowledge unit, the relationship $\mathrm{R}_{\mathrm{UP}}$ between the knowledge unit and the knowledge point, and the relationship $R_{P P}$ between the knowledge point and the knowledge point are abstracted into edges.Because the above knowledge relationships have a causal and logical relationship with each other, the edge of the established course knowledge network is a directed edge.

(3) The course knowledge network node and connected edge update rule set L: Due to changes of knowledge nodes and knowledge relationships (nodes and edges are increased or decreased). And between the course knowledge network and the course knowledge unit sub-network, there is also a mutual influence and role relationship. So, $\mathrm{L}$ represents the update rules of knowledge nodes and connected edges in the course knowledge network.

\section{CONSTRUCTION OF EDUCATIONAL TECHNOLOGY COURSE KNOWLEDGE NETWORK}

\section{A. Data Collection}

This paper selects the course materials as follow: Educational Technology (Version 2, Beijing Normal University Press, He Kekang and Li Wenguang Edited). And the syllabus of the course is used as the main reference. Through a detailed analysis of the text content and structure of the course, then using the graphical representation of knowledge, and analyzing from the two aspects of knowledge nodes and knowledge relations. These knowledge points and their relationship indicate the overall structural characteristics of the Educational Technology course. And this is also to provide specific research data for the construction of the next course knowledge network. The entire collection and collation process of the data is strictly based on the Educational Technology course materials and the corresponding syllabus, in order to ensure that the data materials are comprehensive and true. In the whole process of data collection, the most important process is the extraction of knowledge nodes, and the determination of knowledge relationships. The following focuses on how knowledge nodes and knowledge relationships are determined.

\section{B. Determination of Nodes and Relationships}

\section{1) Extraction of knowledge nodes}

\begin{tabular}{|c|c|c|}
\hline $\begin{array}{c}\text { Serial } \\
\text { number }\end{array}$ & Knowledge unit & Knowledge point \\
\hline 1 & $\begin{array}{c}\text { Educational technology } \\
\text { overview }\end{array}$ & $\begin{array}{c}\text { Basic concepts of educational } \\
\text { technology }\end{array}$ \\
\hline 2 & $\begin{array}{l}\text { History of educational } \\
\text { technology }\end{array}$ & $\begin{array}{c}\text { Aerial view of educational } \\
\text { technology development }\end{array}$ \\
\hline \multirow{2}{*}{3} & \multirow{2}{*}{ education resources } & $\frac{\text {...... }}{\text { Teaching resources overview }}$ \\
\hline & & \\
\hline 4 & Teaching process & learning process \\
\hline 5 & Teaching system design & $\begin{array}{c}\text { Teaching system design } \\
\text { overview }\end{array}$ \\
\hline \multirow[t]{2}{*}{6} & \multirow{2}{*}{$\begin{array}{l}\text { Teaching system } \\
\text { development }\end{array}$} & $\begin{array}{c}\text { Overview of teaching system } \\
\text { development }\end{array}$ \\
\hline & & \\
\hline \multirow[t]{2}{*}{7} & \multirow{2}{*}{$\begin{array}{l}\text { Application of } \\
\text { educational technology }\end{array}$} & $\begin{array}{l}\text { Overview of the use of } \\
\text { educational technology }\end{array}$ \\
\hline & & \\
\hline 8 & $\begin{array}{c}\text { Educational technology } \\
\text { management }\end{array}$ & Teaching resource management \\
\hline \multirow[t]{2}{*}{9} & \multirow{2}{*}{$\begin{array}{l}\text { Teaching resources and } \\
\text { teaching process } \\
\text { evaluation }\end{array}$} & $\begin{array}{c}\text { Educational technology } \\
\text { evaluation category }\end{array}$ \\
\hline & & \\
\hline \multirow[t]{2}{*}{10} & \multirow{2}{*}{$\begin{array}{l}\text { The development of } \\
\text { educational technology } \\
\text { and the deepening of } \\
\text { educational reform }\end{array}$} & $\begin{array}{l}\text { Cultivation of modern } \\
\text { educational technology and } \\
\text { innovative talents }\end{array}$ \\
\hline & & \\
\hline
\end{tabular}

From the analysis of the knowledge content of the Educational Technology course: the course is divided into 10 units, each unit is divided into a number of knowledge points. And by further analyzing the course knowledge content, 1016 knowledge points are extracted. In the process of organizing and analyzing the course knowledge content, according to the unit hierarchy statistics of the course, the issues that need attention during the statistical process: The name of the knowledge unit is also used as the content of the knowledge point. If a repeated knowledge point is encountered, in order to distinguish the difference of the knowledge nodes, it is marked as knowledge point 1 , knowledge point 2, ..., knowledge point $\mathrm{n}$. In addition, when extracting knowledge points, it is mainly to see whether this individual knowledge point can reflect a partial integrity of the knowledge content itself, and whether all of these knowledge points can reflect a global integrity of the Educational Technology course knowledge system. For example, when extracting individual knowledge points in the course, the main contents include: concepts, definitions, theories, applications, methods, categories, and so on. In the process of extracting the entire knowledge node, first based on our own professional basics. Then if we encounter uncertain knowledge points, the corresponding syllabus is referenced, and we ask the guidance of the professional teacher or expert, in order to determine whether to extract it as a knowledge point content. 
The specific statistics on the course knowledge nodes are shown in Table I.

After the collection and collation of knowledge points in the Educational Technology course, all knowledge unit content and knowledge point content are analyzed, and used as knowledge nodes. In this way, all the knowledge content in the Educational Technology course can be visually displayed through the network. It is useful for analyzing and studying the attributes and characteristics of the entire course knowledge network. And it also helps to analyze and study the individual attributes and characteristics of the course knowledge network. After analyzing and extracting all the knowledge content in the Educational Technology course, the number of nodes in the course knowledge network is determined, as shown in Table II.

TABLE II: NUMBER OF NODES IN THE EDUCATIONAL TECHNOLOGY COURSE KNOWLEDGE NETWORK

\begin{tabular}{|c|c|}
\hline Network type & Number of nodes \\
\hline Educational Technology course knowledge network & 1016 \\
\hline
\end{tabular}

All the knowledge nodes collected here are used, and they serve as individual elements in the Educational Technology course knowledge network. In this way, the knowledge node data in the course knowledge network is collected.

\section{2) Determination of knowledge relationship}

After the knowledge nodes of the Educational Technology Course knowledge network are determined, the relationship between the knowledge nodes is established. The knowledge points in the Educational Technology course are complex, and the knowledge points of each unit seem to be independent, but there are various relationships between them. For example, sequential relationship, inclusion relationship, comparison relationship, classification relationship, same relationship, parallel relationship, repeated relationship, and so on. The following is a list of examples to illustrate the knowledge relationship of the Educational Technology course, as shown in Table III.

TABLE III: KNOWLEDGE RELATIONSHIP EXAMPLES ANALYSIS

\begin{tabular}{|c|l|}
\hline $\begin{array}{c}\text { Knowledge } \\
\text { relationship }\end{array}$ & \multicolumn{1}{c|}{ List of examples } \\
\hline $\begin{array}{c}\text { sequential } \\
\text { relationship }\end{array}$ & $\begin{array}{l}\text { The overview of educational technology and the } \\
\text { history of educational technology have a sequential } \\
\text { learning relationship. }\end{array}$ \\
\hline $\begin{array}{c}\text { inclusion } \\
\text { relationship }\end{array}$ & $\begin{array}{l}\text { The overview of educational technology includes the } \\
\text { basic concepts of educational technology. }\end{array}$ \\
\hline $\begin{array}{c}\text { classification } \\
\text { relationship }\end{array}$ & $\begin{array}{l}\text { Teaching resources can be divided into hardware, } \\
\text { software resources and human, non-human } \\
\text { resources. }\end{array}$ \\
\hline $\begin{array}{c}\text { same } \\
\text { relationship }\end{array}$ & $\begin{array}{l}\text { Educational technology is also known as technical } \\
\text { education. }\end{array}$ \\
\hline $\begin{array}{c}\text { comparison } \\
\text { relationship }\end{array}$ & $\begin{array}{l}\text { The AECT'05 educational technology definition has } \\
\text { a comparative relationship with the AECT'94 } \\
\text { educational technology definition. }\end{array}$ \\
\hline $\begin{array}{c}\text { parallel } \\
\text { relationship } \\
\text { educational technology has a parallel relationship } \\
\text { with the development of educational technology in } \\
\text { China. }\end{array}$ \\
\hline $\begin{array}{c}\text { repeated } \\
\text { relationship }\end{array}$ & $\begin{array}{l}\text { The learning process 1 has a repetitive relationship } \\
\text { with the learning process 2. }\end{array}$ \\
\hline
\end{tabular}

According to the knowledge relationship listed above, 1016 knowledge nodes are analyzed one by one, and the corresponding knowledge relationship is determined. If a knowledge node is associated with another knowledge node, the corresponding knowledge relationship is marked as 1, otherwise it is marked as 0. For example, the knowledge point “AECT'05 Educational Technology definition" has a comparative knowledge relationship with the knowledge point “AECT'94 Educational Technology definition”, this is marked as 1 . In this way, the number of relationships in the Educational Technology course knowledge network can be determined, as shown in Table IV.

TABLE IV: NUMBER OF RELATIONSHIPS IN THE EDUCATIONAL TECHNOLOGY COURSE KNOWLEDGE NETWORK

\begin{tabular}{|c|c|} 
TECHNOLOGY COURSE KNOWLEDGE NETWORK \\
\hline Network type & Number of relationships \\
\hline $\begin{array}{c}\text { Educational Technology course } \\
\text { knowledge network }\end{array}$ & 10721 \\
\hline
\end{tabular}

Through the above analysis of 1016 knowledge nodes, then the corresponding knowledge relationship is can be determined. And the adjacency matrix of the course knowledge network can be established, this is to clearly show the knowledge relationship between each knowledge node.

\section{Construction of Course Knowledge Network Topology Map}

According to the predefined course knowledge network model, then based on the determined knowledge nodes and knowledge relationships, and UCINET software is used to construct the Educational Technology course knowledge network. The course knowledge network topology map is shown in Fig. 1.

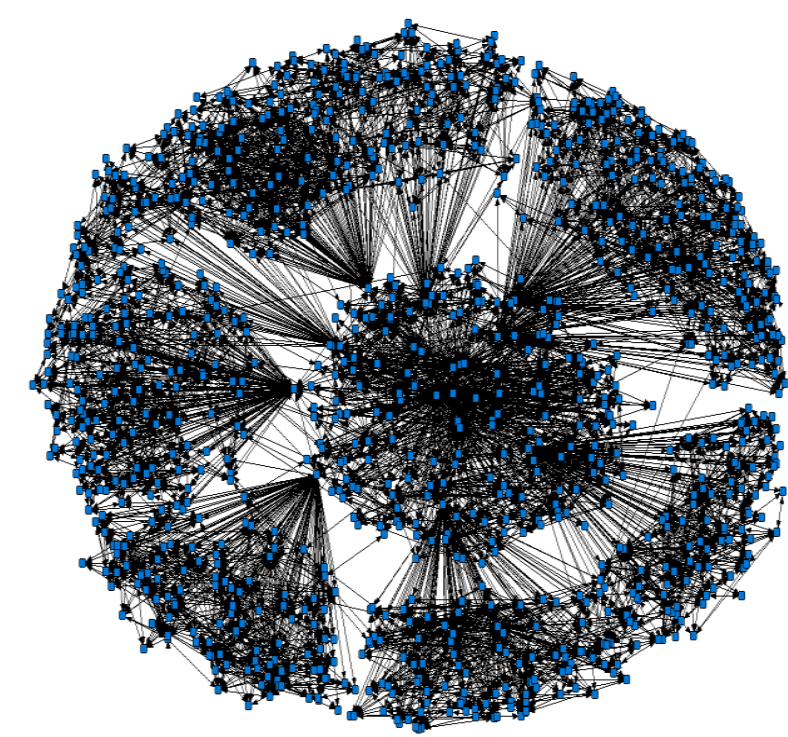

Fig. 1. Educational Technology course knowledge network topology map.

Through the Educational Technology course knowledge network topology map, we can see: By comparing with traditional methods, it is more objective, comprehensive and intuitive to describe the overall characteristics of the course knowledge structure. However, we also found: the hierarchical structure of knowledge points is not very clear, and the main lines and ideas of learning are not very clear. And the learning of knowledge points is too dependent on the relationship between knowledge points. This is not conducive to the learning of knowledge points, and it will easily confuse knowledge points. So, in order to improve the clarity of the course knowledge network and to highlight the key information of the course knowledge structure, the course knowledge structure will be optimized next by using the method of topological sorting based on directed graphs. 


\section{OPTIMIZATION OF EDUCATIONAL TECHNOLOGY COURSE KNOWLEDGE STRUCTURE}

\section{A. Optimization Method of Topological Sorting Based on Directed Graph}

We discuss the optimization problem of the course knowledge structure in the next. If the knowledge node is used to represent the learning activity of knowledge point, and the directed edge indicates the priority relationship between the knowledge points. Then the entire learning activity process can be represented by a "directed graph". Thence, the learning activity process of the entire course knowledge content can be transformed into a directed graph. And the topological relationship between knowledge nodes is presented in the form of an adjacency matrix. By using this method, a topological sorting model based on directed graphs is established. At the same time, a directed graph is also drawn. This can clearly express the main line of knowledge and learning ideas, and achieve the goal of optimizing the course knowledge structure.

Here, a directed graph generated by the Educational Technology course knowledge network, it expresses an AOV network that represents learning activities. And it can clearly indicate the priority relationship between knowledge points, and visually show the order and hierarchical relationship between knowledge points. This directed graph is a data structure diagram, and it consists of a collection of nodes and a collection of relationships [11]. The representation of this data structure model is the same as that of the course knowledge network model. In the AOV learning activity network, if the knowledge node $\mathrm{v}_{\mathrm{i}}$ is the precursor of the knowledge node $v_{j}$, then $v_{i}$ must be in front of $v_{j}$. That is, the learning activity of the knowledge node $v_{i}$ must be earlier than the learning activity of the knowledge node $v_{j}$. In addition, this AOV learning activity network has only direct precursors and successors, and there is no directed ring [12]. As a result, the definition of the optimized course knowledge network has only a sequential learning relationship. That is, the learning of knowledge points has a sequence or precursor, and there is no closed loop. According to such a method, the principle technique based on ordered graph topological ordering can be applied to the research of optimizing the course knowledge structure.

Next, the optimization method based on the directed graph topological ordering is used to further optimize the knowledge structure of the Educational Technology course. In the process of optimizing the course knowledge structure, the content of the knowledge node is not changed. When learning the repeated knowledge points, the teacher only needs to simply explain the repeated knowledge points, and also allows the students to learn independently. In addition, it is necessary to optimize some knowledge relationships. That is, on the basis of the original knowledge relationship, only the knowledge relationship with clear knowledge main line and learning ideas is retained. And the knowledge relationship that causes learning interference is deleted. That is , only the successive knowledge relationships are retained, and this can reflect the order and hierarchy of the course knowledge structure. At the same time, this will make the knowledge content and knowledge framework of the course clearer, and the learning the main line and learning ideas will be clearer.

\section{B. Optimized Course Knowledge Network}

Now, the same method is used, in order to analyze 1016 knowledge nodes again. Then the number of optimized knowledge relationships is determined. The number of relationships in the optimized Educational Technology courses knowledge network is shown in Table V.

TABLE V: NUMBER OF RELATIONSHIPS IN THE OPTIMIZED COURSE KNOWLEDGE NETWORK

\begin{tabular}{|c|c|}
\hline Network Type & Number of relationships \\
\hline $\begin{array}{c}\text { Educational Technology course knowledge } \\
\text { network }\end{array}$ & 2037 \\
\hline
\end{tabular}

In this way, according to the optimized knowledge relationship, the optimized adjacency matrix of the course knowledge network can be established again, and the optimized Educational Technology course knowledge network topology map is further constructed, as shown in Fig. 2. As we can be seen from this figure: After optimization, the course knowledge structure forms the structural model of "trunk-branch". At the same time, the course knowledge structure also forms the structural feature of "hierarchical-modular". This more clearly shows the successive relationships of different knowledge points in the overall knowledge structure. After optimization, the knowledge level and framework of the course are clearer, and the learning the main line and ideas are clearer. So, it can better reflect the layering, order and structure of the course overall knowledge structure, and truly reflect the superiority of the optimized course knowledge structure.

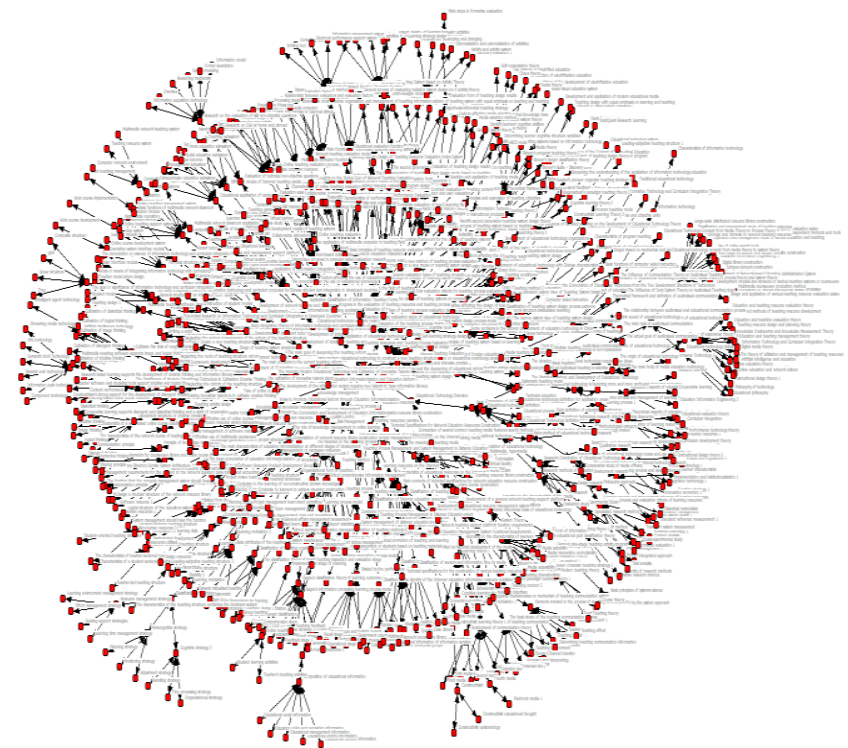

Fig. 2. Optimized educational technology course knowledge network topology map.

Next, based on the optimized course knowledge network established above, and in order to further highlight the characteristics and advantages of the optimized course knowledge structure, the structure and attributes of the pre-optimized and optimized course knowledge network are comparatively analyzed. And the superiority of the optimized course knowledge structure is further explained. Here, an evaluation system for the comparative analysis of the Educational Technology course knowledge network is 
established, as shown in Fig. 3. Then, according to the evaluation system, it is possible to compare and analyze the Educational Technology course knowledge network before and after optimization.

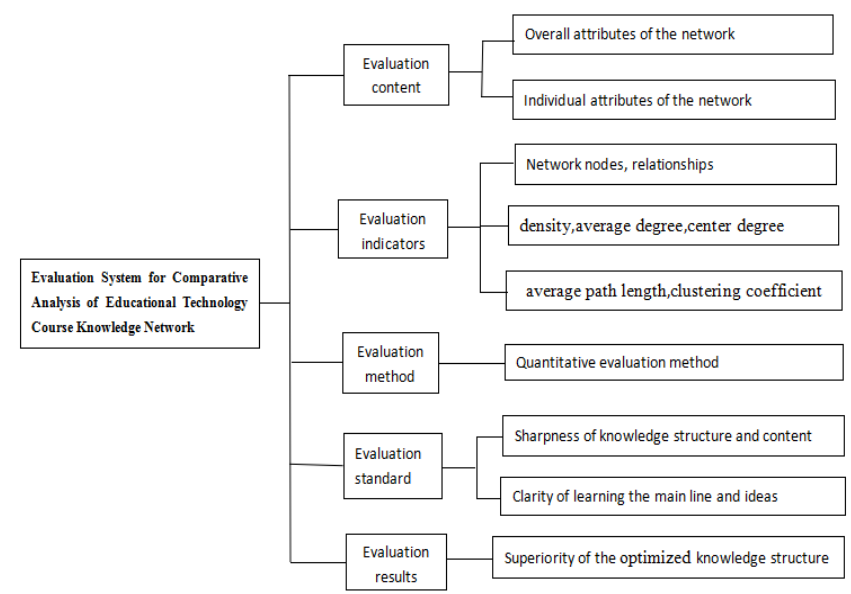

Fig. 3. Evaluation system for comparative analysis of the pre-optimized and optimized Educational Technology course knowledge network.

\section{Comparative Analysis of the Overall Structure of the Course Knowledge Network}

Firstly, the evaluation system based on comparative analysis, the overall structural of the pre-optimized and optimized Educational Technology course knowledge network are compared and analyzed. Mainly from the following indicators for comparative analysis: Number of nodes and relationships, average degree, density, clustering coefficient, average path length. The specific analysis results and optimization comparison statistics are shown in Table VI.

TABLE VI: EDUCATIONAL TECHNOLOGY COURSE KNOWLEDGE NETWORK OVERALL STRUCTURE OPTIMIZATION COMPARISON STATISTICS

\begin{tabular}{|c|c|c|}
\hline Indicator name & Pre-optimized network & Optimized network \\
\hline Number of nodes & 1016 & 1016 \\
\hline $\begin{array}{c}\text { Number of } \\
\text { relationships }\end{array}$ & 10721 & 2037 \\
\hline Network density & 0.01 & 0.002 \\
\hline Average degree & 10.552 & 2.003 \\
\hline $\begin{array}{c}\text { Clustering } \\
\text { coefficient }\end{array}$ & 0.866 & 0.002 \\
\hline $\begin{array}{c}\text { Average path } \\
\text { length }\end{array}$ & 2.858 & 8.437 \\
\hline $\begin{array}{c}\text { Maximum path } \\
\text { length }\end{array}$ & 3 & 14 \\
\hline
\end{tabular}

\section{1) Comparative analysis of network size and density before and after optimization}

It can be seen from Table VI as follows: after optimization, the knowledge node of the Educational Technology course knowledge network has not changed. But the knowledge relationship has been reduced a lot. The density has also decreased, and it is reduced from the original 0.01 to 0.002 . This shows that the relationship between knowledge nodes is reduced, the tightness and complexity of the network structure are reduced, and the boundary of knowledge points is clearer. This reduces the disruptiveness and confusion of learning, and it also shows that the knowledge level and structure are clearer after optimization, the main line of knowledge and learning ideas are clearer.
2) Comparative analysis of average degree before and after optimization

In the pre-optimized Educational Technology course knowledge network, the average degeree is 10.552. After optimization, the average degree of the course knowledge network is reduced to 2.003. This shows the average number of knowledge nodes associated with other nodes is reduced from 10.552 to 2.003 . And it shows that the connection of the whole network node is reduced, the independence of learning between knowledge points is enhanced. This also shows that when learning the course, not only should master the content of the knowledge point itself, but also further optimize the main line and ideas of learning between knowledge points. And this is to make learning more sequential and structured. (3) Comparative analysis of average path length before and after optimization

In the pre-optimized Educational Technology course knowledge network, the maximum path length is 3 , and the average path length is 2.858 . This means that if a knowledge node affects another knowledge node in the course knowledge network, it needs to pass 2.858 connected edges. In the optimized course knowledge network, the maximum path length is 14 , and the average path length is 8.437 . This means that if a knowledge node affects another knowledge node in the network, it needs to pass 8.437 connected edges. This also shows that the relationship between the knowledge points is reduced after optimization, the path distance is increased, and each knowledge point is more independent. In the process of learning various knowledge points, on the basis of mastering the knowledge points themselves, we should further optimize the main line of knowledge point learning, and clarify the ideas of knowledge point learning.

(4) Comparative analysis of clustering coefficient before and after optimization

The clustering coefficient of the pre-optimized Educational Technology course knowledge network is 0.866 , which shows that the knowledge content in the network has community integration characteristics. After optimization, the clustering coefficient of the network is 0.002, and the clustering coefficient of the network is reduced a lot. After optimization, each knowledge node is divided separately, and each knowledge point plays its own role, then the independence of knowledge points is enhanced. However, the stability of the network is reduced. When some knowledge points are lost, many knowledge points will be affected, and even the entire network will be affected. This also reflects the importance of the overall knowledge structure. So, in the process of learning, we should follow the order of learning, pay attention to the learning of each knowledge point, and focus on the main line of knowledge and learning ideas of the overall content.

\section{Comparative Analysis of Individual Attribute of Course Knowledge Network}

Then based on the evaluation system of comparative analysis, the individual attributes of the pre-optimized and optimized Educational Technology course knowledge network are compared and analyzed. And it mainly analyzes the influence of some knowledge nodes in the course knowledge network, these three indicators are used: degree centrality, betweenness centrality, closeness centrality. 
1) Comparative analysis of degree centrality before and after optimization

TABLE VII: DEGREE CENTRALITY IN THE EDUCATIONAL TECHNOLOGY COURSE KNOWLEDGE NETWORK BEFORE AND AFTER OPTIMIZATION (TOP 15)

\begin{tabular}{|c|c|c|c|c|}
\hline & \multicolumn{2}{|c|}{ Before optimization } & \multicolumn{2}{|c|}{ After optimization } \\
\hline NO & Knowledge node & $\begin{array}{c}\text { Degree } \\
\text { centrality }\end{array}$ & $\begin{array}{l}\text { Knowledge } \\
\text { node }\end{array}$ & $\begin{array}{c}\text { Degree } \\
\text { centrality }\end{array}$ \\
\hline 1 & $\begin{array}{c}\text { Educational } \\
\text { technology } \\
\text { overview }\end{array}$ & 388 & $\begin{array}{l}\text { Application of } \\
\text { various } \\
\text { informational } \\
\text { teaching forms }\end{array}$ & 42 \\
\hline 2 & $\begin{array}{l}\text { Teaching system } \\
\text { design }\end{array}$ & 278 & $\begin{array}{c}\text { Applied science } \\
\text { part of } \\
\text { educational } \\
\text { technology }\end{array}$ & 34 \\
\hline 3 & $\begin{array}{l}\text { Basic concepts } \\
\text { of educational } \\
\text { technology }\end{array}$ & 250 & $\begin{array}{l}\text { Basic theory } \\
\text { part of } \\
\text { educational } \\
\text { technology }\end{array}$ & 32 \\
\hline 4 & $\begin{array}{c}\text { Teaching system } \\
\text { development }\end{array}$ & 244 & Teaching theory & 24 \\
\hline 5 & $\begin{array}{l}\text { Teaching } \\
\text { process }\end{array}$ & 226 & $\begin{array}{c}\text { Teaching } \\
\text { system design } \\
\text { mode based on } \\
\text { learning } \\
\end{array}$ & 20 \\
\hline 6 & $\begin{array}{l}\text { Application of } \\
\text { educational } \\
\text { technology }\end{array}$ & 218 & $\begin{array}{l}\text { Research } \\
\text { orientation of } \\
\text { educational } \\
\text { technology }\end{array}$ & 18 \\
\hline 7 & $\begin{array}{l}\text { education } \\
\text { resources }\end{array}$ & 212 & $\begin{array}{c}\text { Teaching } \\
\text { process }\end{array}$ & 18 \\
\hline 8 & $\begin{array}{l}\text { History of } \\
\text { educational } \\
\text { technology }\end{array}$ & 206 & $\begin{array}{c}\text { R. Găgne } \\
\text { information } \\
\text { processing } \\
\text { learning process } \\
\text { model }\end{array}$ & 18 \\
\hline 9 & $\begin{array}{l}\text { Educational } \\
\text { technology } \\
\text { management }\end{array}$ & 170 & $\begin{array}{c}\text { The basic } \\
\text { process of } \\
\text { online course } \\
\text { development }\end{array}$ & 18 \\
\hline 10 & $\begin{array}{c}\text { Teaching } \\
\text { resources and } \\
\text { teaching process } \\
\text { evaluation }\end{array}$ & 144 & $\begin{array}{c}\text { School } \\
\text { comprehensive } \\
\text { information } \\
\text { management }\end{array}$ & 18 \\
\hline 11 & $\begin{array}{l}\text { The theoretical } \\
\text { basis of } \\
\text { educational } \\
\text { technology }\end{array}$ & 124 & $\begin{array}{l}\text { Elements } \\
\text { involved in the } \\
\text { process of } \\
\text { teaching } \\
\text { communication }\end{array}$ & 16 \\
\hline 12 & $\begin{array}{l}\text { The general } \\
\text { scientific } \\
\text { theoretical basis } \\
\text { of educational } \\
\text { technology }\end{array}$ & 116 & $\begin{array}{l}\text { Audiovisual } \\
\text { communication }\end{array}$ & 16 \\
\hline 13 & learning process & 114 & $\begin{array}{c}\text { Theoretical } \\
\text { framework of } \\
\text { educational } \\
\text { technology with } \\
\text { Chinese } \\
\text { characteristics }\end{array}$ & 16 \\
\hline 14 & $\begin{array}{l}\text { The disciplinary } \\
\text { nature and } \\
\text { development of } \\
\text { educational } \\
\text { technology }\end{array}$ & 110 & $\begin{array}{l}\text { Analysis of the } \\
\text { design process } \\
\text { of teaching } \\
\text { system based on } \\
\text { teaching }\end{array}$ & 16 \\
\hline 15 & $\begin{array}{c}\text { The } \\
\text { development of } \\
\text { educational } \\
\text { technology and } \\
\text { the deepening of } \\
\text { educational } \\
\text { reform }\end{array}$ & 108 & $\begin{array}{l}\text { The } \\
\text { composition of } \\
\text { the electronic } \\
\text { performance } \\
\text { support system }\end{array}$ & 16 \\
\hline
\end{tabular}

The ranking comparison of the degree centrality of the pre-optimized and optimized Educational Technology course knowledge network is shown in Table VII. It can be seen from this table as follows: The degree centrality of the pre-optimized and optimized knowledge nodes has changed a lot. After optimization, it reflects the influence and ability of specific knowledge points. For example: "Application of various informational teaching forms", "Applied science part of educational technology", "Basic theoretical part of educational technology", etc. These sub-knowledge points also include a lot of subsequent sub-knowledge points, which are the "hub point" of knowledge content learning in each unit, and which is also the key content of learning. In the foundation of knowledge line and learning ideas, these sub-knowledge points are also located in important positions. And the learning of these subsequent sub-knowledge points should not be neglected in the learning process.

\section{2) Comparative analysis of betweenness centrality before and after optimization}

TABLE VIII: BETWEENNESS CENTRALITY IN THE EDUCATIONAL TECHNOLOGY COURSE KNOWLEDGE NETWORK BEFORE AND AFTER OPTIMIZATION (TOP 15)

\begin{tabular}{|c|c|c|c|c|}
\hline & \multicolumn{2}{|c|}{ Before optimization } & \multicolumn{2}{|c|}{ After optimization } \\
\hline NO & $\begin{array}{l}\text { Knowledge } \\
\text { node }\end{array}$ & $\begin{array}{l}\text { Betweennes } \\
\text { s centrality }\end{array}$ & $\begin{array}{l}\text { Knowledge } \\
\text { node }\end{array}$ & $\begin{array}{c}\text { Betweenness } \\
\text { centrality }\end{array}$ \\
\hline 1 & $\begin{array}{l}\text { Educational } \\
\text { technology } \\
\text { overview }\end{array}$ & 317832.126 & $\begin{array}{c}\text { Teaching } \\
\text { system design }\end{array}$ & 217402 \\
\hline 2 & $\begin{array}{c}\text { Teaching system } \\
\text { design }\end{array}$ & 237737.221 & $\begin{array}{c}\text { Teaching } \\
\text { system } \\
\text { development }\end{array}$ & 193162 \\
\hline 3 & $\begin{array}{c}\text { Teaching system } \\
\text { development }\end{array}$ & 212427.495 & $\begin{array}{l}\text { Teaching } \\
\text { process }\end{array}$ & 175742 \\
\hline 4 & $\begin{array}{l}\text { Teaching } \\
\text { process }\end{array}$ & 193038.976 & $\begin{array}{l}\text { Application } \\
\text { of educational } \\
\text { technology }\end{array}$ & 172018 \\
\hline 5 & $\begin{array}{l}\text { Application of } \\
\text { educational } \\
\text { technology }\end{array}$ & 189195.410 & $\begin{array}{c}\text { Educational } \\
\text { technology } \\
\text { overview }\end{array}$ & 168863 \\
\hline 6 & $\begin{array}{l}\text { education } \\
\text { resources }\end{array}$ & 183190.800 & $\begin{array}{l}\text { education } \\
\text { resources }\end{array}$ & 166064 \\
\hline 7 & $\begin{array}{l}\text { History of } \\
\text { educational } \\
\text { technology }\end{array}$ & 179718.995 & $\begin{array}{l}\text { History of } \\
\text { educational } \\
\text { technology }\end{array}$ & 162158 \\
\hline 8 & $\begin{array}{c}\text { Educational } \\
\text { technology } \\
\text { management }\end{array}$ & 145746.617 & $\begin{array}{l}\text { Educational } \\
\text { technology } \\
\text { management }\end{array}$ & 132986 \\
\hline 9 & $\begin{array}{c}\text { Teaching } \\
\text { resources and } \\
\text { teaching process } \\
\text { evaluation }\end{array}$ & 121644.100 & $\begin{array}{c}\text { Basic } \\
\text { concepts of } \\
\text { educational } \\
\text { technology }\end{array}$ & 127655 \\
\hline 10 & $\begin{array}{c}\text { The } \\
\text { development of } \\
\text { educational } \\
\text { technology and } \\
\text { the deepening of } \\
\text { educational } \\
\text { reform }\end{array}$ & 88578.167 & $\begin{array}{l}\text { Teaching } \\
\text { resources and } \\
\text { teaching } \\
\text { process } \\
\text { evaluation }\end{array}$ & 111256 \\
\hline 11 & $\begin{array}{l}\text { Basic concepts } \\
\text { of educational } \\
\text { technology }\end{array}$ & 7556.060 & $\begin{array}{l}\text { learning } \\
\text { process }\end{array}$ & 95758 \\
\hline 12 & learning process & 1913.467 & $\begin{array}{l}\text { Teaching } \\
\text { process }\end{array}$ & 85776 \\
\hline 13 & $\begin{array}{l}\text { The theoretical } \\
\text { basis of } \\
\text { educational } \\
\text { technology }\end{array}$ & 1471.543 & $\begin{array}{l}\text { The } \\
\text { development } \\
\text { of educational } \\
\text { technology } \\
\text { and the } \\
\text { deepening of } \\
\text { educational } \\
\text { reform }\end{array}$ & 80224 \\
\hline 14 & $\begin{array}{l}\text { Teaching system } \\
\text { design overview }\end{array}$ & 1203.333 & $\begin{array}{c}\text { Teaching } \\
\text { system design } \\
\text { overview }\end{array}$ & 78740 \\
\hline 15 & $\begin{array}{l}\text { The general } \\
\text { scientific } \\
\text { theoretical basis } \\
\text { of educational } \\
\text { technology }\end{array}$ & 1198.710 & $\begin{array}{l}\text { media } \\
\text { resources }\end{array}$ & 73544 \\
\hline
\end{tabular}

The sorting comparison of the betweenness centrality of the pre-optimized and optimized Educational Technology course knowledge network is shown in Table VIII. It can be seen from this table as follows: The maximum betweenness centrality of the pre-optimization course knowledge network is 317832.126 , the minimum value is 0 , the average value is 1886.208 , and the maximum value is 168.50 times of the average value. After optimization, the maximum value of the 
betweenness centrality of the course knowledge network is 217402 , the minimum value is 0 , the average value is 6425.912 , and the maximum value is 33.832 times of the average value. It can be concluded: the heterogeneity of the betweenness centrality of the Educational Technology course knowledge network is gradually reduced. Among them, there are 691 knowledge nodes, and their betweenness centrality is 0 . It indicates that there is still only a part of knowledge content as the "connection point" of other knowledge content learning. And there is also a part of knowledge content in the edge knowledge point, there is almost no intermediary connection ability. In addition, as can be seen from the table: The optimized knowledge node changes are not very large, the original title knowledge content is reflected, for example: "Teaching system design", "Teaching system development", "Teaching process", etc. These title knowledge contents have important connectivity skills in the course, and they are the bridge connecting the specific knowledge points under the title content. These knowledge contents have important connectivity skills, which have a great impact on the whole course learning. As a result, it is still the focus of the learning process.

\section{3) Comparative analysis of closeness centrality before and after optimization}

The sorting comparison of the closeness centrality of the pre-optimized and optimized Educational Technology course knowledge network is shown in Table IX. It can be seen from this table as follows: The pre-optimized and optimized knowledge nodes have not changed much. This shows that the knowledge nodes that can be used as difficult content have not changed much, and they are still the title knowledge content in the course. This is because the title content includes many sub-knowledge points, which are difficult to understand and master. And this needs more time to learn, which increases the difficulty of learning. After optimization, these title knowledge contents still has certain relevance, and they still need to be learned as difficult knowledge content. However, from the value of the closeness centrality, they are smaller than before optimization. This shows that the relationship between knowledge nodes is reduced after optimization, the degree of intimacy is reduced, and the independence is enhanced, the knowledge line and learning ideas are clearer. Thus the learning difficulty is reduced.

TABLE IX: ClOSENESS CENTRALITY IN THE EDUCATIONAL TECHNOLOGY COURSE KNOWLEDGE NETWORK BEFORE AND AFTER OPTIMIZATION (TOP

\begin{tabular}{|c|c|c|c|c|}
\hline & \multicolumn{2}{|c}{ Before optimization } & \multicolumn{2}{c|}{ After optimization } \\
\hline NO & $\begin{array}{c}\text { Knowledge } \\
\text { node }\end{array}$ & $\begin{array}{c}\text { Closeness } \\
\text { centrality }\end{array}$ & Knowledge node & $\begin{array}{c}\text { Closeness } \\
\text { centrality }\end{array}$ \\
\hline 1 & $\begin{array}{c}\text { Educational } \\
\text { technology } \\
\text { overview }\end{array}$ & 0.553 & $\begin{array}{c}\text { Teaching system } \\
\text { design }\end{array}$ & 0.202 \\
\hline 2 & $\begin{array}{c}\text { Teaching } \\
\text { system design }\end{array}$ & 0.537 & $\begin{array}{c}\text { Teaching system } \\
\text { development }\end{array}$ & 0.200 \\
\hline 3 & $\begin{array}{c}\text { Teaching } \\
\text { system } \\
\text { development }\end{array}$ & 0.532 & $\begin{array}{c}\text { Teaching } \\
\text { process }\end{array}$ & 0.199 \\
\hline 5 & $\begin{array}{c}\text { Teaching } \\
\text { process }\end{array}$ & 0.529 & $\begin{array}{c}\text { Application of } \\
\text { educational } \\
\text { technology }\end{array}$ & 0.199 \\
\hline 6 & $\begin{array}{c}\text { Application of } \\
\text { educational } \\
\text { technology }\end{array}$ & 0.528 & $\begin{array}{c}\text { education } \\
\text { resources }\end{array}$ & 0.198 \\
\hline education & 0.528 & $\begin{array}{c}\text { History of } \\
\text { educational } \\
\text { technology }\end{array}$ & 0.198 \\
\hline
\end{tabular}

\begin{tabular}{|c|c|c|c|c|}
\hline 7 & $\begin{array}{l}\text { History of } \\
\text { educational } \\
\text { technology }\end{array}$ & 0.527 & $\begin{array}{l}\text { Educational } \\
\text { technology } \\
\text { management }\end{array}$ & 0.196 \\
\hline 8 & $\begin{array}{l}\text { Educational } \\
\text { technology } \\
\text { management }\end{array}$ & 0.522 & $\begin{array}{c}\text { Teaching } \\
\text { resources and } \\
\text { teaching process } \\
\text { evaluation }\end{array}$ & 0.195 \\
\hline 9 & $\begin{array}{l}\text { Teaching } \\
\text { resources and } \\
\text { teaching } \\
\text { process } \\
\text { evaluation } \\
\end{array}$ & 0.518 & $\begin{array}{l}\text { Educational } \\
\text { technology } \\
\text { overview }\end{array}$ & 0.195 \\
\hline 10 & $\begin{array}{c}\text { The } \\
\text { development of } \\
\text { educational } \\
\text { technology and } \\
\text { the deepening } \\
\text { of educational } \\
\text { reform }\end{array}$ & 0.514 & $\begin{array}{c}\text { The } \\
\text { development of } \\
\text { educational } \\
\text { technology and } \\
\text { the deepening of } \\
\text { educational } \\
\text { reform }\end{array}$ & 0.194 \\
\hline 11 & $\begin{array}{l}\text { Basic concepts } \\
\text { of educational } \\
\text { technology }\end{array}$ & 0.375 & $\begin{array}{l}\text { Teaching system } \\
\text { design overview }\end{array}$ & 0.171 \\
\hline 12 & $\begin{array}{c}\text { Teaching } \\
\text { system design }\end{array}$ & 0.374 & learning process & 0.170 \\
\hline 13 & $\begin{array}{c}\text { The theoretical } \\
\text { basis of } \\
\text { educational } \\
\text { technology }\end{array}$ & 0.366 & $\begin{array}{c}\text { Teaching system } \\
\text { design mode } \\
\text { based on } \\
\text { teaching }\end{array}$ & 0.170 \\
\hline 14 & $\begin{array}{l}\text { The general } \\
\text { scientific } \\
\text { theoretical basis } \\
\text { of educational } \\
\text { technology }\end{array}$ & 0.366 & $\begin{array}{l}\text { Basic concepts } \\
\text { of educational } \\
\text { technology }\end{array}$ & 0.170 \\
\hline 15 & learning process & 0.365 & $\begin{array}{l}\text { Progress in the } \\
\text { design of } \\
\text { teaching systems }\end{array}$ & 0.170 \\
\hline
\end{tabular}

\section{Teaching Suggestions Based on PRE-OPtimized AND OPTIMIZED EDUCATIONAL TECHNOLOGY COURSE KNOWLEDGE NETWORK ANALYSIS RESULTS}

Based on the comparative analysis of the pre-optimized and optimized Educational Technology course knowledge network structure and attributes, the superiority of the optimized course knowledge structure can be obtained. Here, the final question that deserves our deep thought: How should teachers actually achieve the goal of optimizing teaching based on the results of comparative analysis? That is, what are the key recommendations of teachers in the teaching process? Next, based on the results of the comparative analysis of the above pre-optimized and optimized Educational Technology course knowledge network, the following two teaching suggestions are proposed:

Firstly, based on the comparative analysis of the overall attributes of the pre-optimized and optimized Education Technology course knowledge network, the analysis results can be obtained: After optimization, the network density is reduced to 0.002 , the average degree is reduced to 2.003 , the average path length is increased to 8.437 , and the average clustering coefficient is reduced to 0.002 . This shows that the network relationship is reduced after optimization, the complexity and tightness is reduced. This reflects that the interference of knowledge point learning is weakened, the independence is enhanced, and the main line and ideas of the overall knowledge structure learning are clarified. However, the stability of the network structure is reduced. When a certain knowledge point is lost, the entire network may be affected, which indicates the importance of the course overall knowledge structure. Therefore, in the teaching process, teachers should pay attention to the course overall knowledge structure, and pay attention to integrating the knowledge structure of each unit. Teachers should optimize the teaching line and ideas of the course overall knowledge structure, and 
conduct sequential and structural teaching according to the overall knowledge structure. Let students first have an overall understanding of the course, and let the students understand the overall framework of the course. This is to cultivate students' cognitive structure of the whole course, and to improve the teaching efficiency of teachers in the teaching process. So, based on the comparative analysis of the overall attributes of the pre-optimized and optimized Educational Technology course knowledge network, teaching suggestions can be inferred: We should pay attention to the course overall knowledge structure, and optimize the main line of teaching and teaching ideas.

Secondly, based on the comparative analysis of the individual attributes of the pre-optimized and optimized Educational Technology course knowledge network, the analysis results can be obtained: After optimization, from the analysis of the degree centrality, betweenness centrality and closeness centrality of the network node, The important knowledge nodes have changed, not just the title knowledge content, but also the specific sub-knowledge points. For example: "Application of various informational teaching forms", "The applied science part of educational technology", "The basic theoretical part of educational technology", etc. These sub-knowledge points also include many subsequent sub-knowledge points, which also play an important role in the learning process. In addition, the maximum value of the betweenness centrality is 33.832 times of the average value, the gap is much smaller than before optimization. And the network's closeness centrality value is also reduced after optimization. This shows that the heterogeneity between the knowledge points is reduced after optimization, the learning interference of each knowledge point is weakened, the independence is enhanced, and the main lines and ideas of learning between the knowledge points are clarified. Thus, the difficulty of learning the knowledge points is reduced. Therefore, in the teaching process, teachers should not only regard the title knowledge content as the important and difficult point of teaching, but also further analyze the specific sub-knowledge point. This is to find more specific and detailed important and difficult point of teaching, to reduce the interference of knowledge relations, and to increase the independence of knowledge content. This can clarify the main line of knowledge and learning ideas, and reduce the difficulty of teaching. And this can make the teaching content more specific, make the teaching objectives are more clear. Thus, the teaching efficiency of teachers in the teaching process is improved. So, based on the comparative analysis of the individual attributes of the pre-optimized and optimized Educational Technology course knowledge network, teaching suggestions can be inferred: We should grasp the important and difficult point of the course, and optimize the teaching content and teaching objectives.

\section{CONCLUSION}

This paper mainly constructed the Educational Technology course knowledge network based on complex networks, and further optimized the course knowledge structure. Then combined with the actual teaching problems, from the two aspects of the overall attributes and individual attributes of the network, the pre-optimized and optimized course knowledge network are comparatively analyzed, and the superiority of the optimized course knowledge structure is explained. Finally, based on the results of comparative analysis of the pre-optimized and optimized course knowledge network, the corresponding teaching suggestions are proposed in the teaching process. However, there is still a lot of research space for the constructed course knowledge network. In the future research work, it is necessary to continuously combine the actual teaching characteristics, and adopting more advanced optimization methods to further optimize the course knowledge structure. At the same time, more targeted teaching suggestions are proposed, this is to truly achieve the purpose of optimizing teaching.In addition, the construction and research of the course knowledge network can be extended to the teaching fields of other courses.

\section{CONFLICT OF INTEREST}

The authors declare no conflict of interest.

\section{AUTHOR CONTRIBUTIONS}

Jingxia Liu and Bin Wen conducted the research; Jingxia Liu and Bin Wen analyzed the data; Jingxia Liu and Bin Wen wrote the paper; all authors had approved the final version.

\section{ACKNOWLEDGMENT}

The research is supported by a National Nature Science Fund Project (Nos. 61661051), Key Laboratory of Education Information of Nationalities Ministry of Education, Yunnan Key Laboratory of Smart Education, Program for Innovative Research Team (in Science and Technology) in University of Yunnan Province, and Kunming Key Laboratory of Education Information.

\section{REFERENCES}

[1] Notice of the Ministry of Education on Printing and Distributing the 13th Five-Year Plan for Education Informationization [EB/OL]. (2016). [Online]. Available: http://www.moe.edu.cn/srcsite/A16/s3342/201606/t20160622_26936 7.html

[2] Y. K. Miao, "Knowledge cognitive navigation system based on network construction - Prototype realization of application electric technology discipline," M.S. thesis, East China Normal University, China, 2007.

[3] Z. Peng and Y. X. Guo, "Research on knowledge structure model of teaching materials based on complex network theory - Taking junior middle school physics textbook as an example," Theory and Practice of Education, vol. 37, pp. 42-45, 2017

[4] D. X. Wan, "Research of network curriculum resource designing based on knowledge points," M.S. thesis, Shenyang Normal University, China, 2017.

[5] X. Y. Liu, "The research of knowledge connection and its application," M.S. thesis, Xiangtan University, China, 2010.

[6] Y. M. Sun, "Research on characteristics of network structure of knowledge points in chemistry textbooks," M.S. thesis, East China Normal University, China, 2018.

[7] X. Xu, Q. Zhang, Y. L. Zhang et al., "On the application of complex network concepts in the areas of educational technology," Journal of Ningbo University (Education Science), vol. 36, no. 6, pp. 89-93, 2014.

[8] J. X. Liu and B. Wen, "Construction and analysis of knowledge network: On the example of educational technology syllabus," International Journal of Information and Education Technology, vol. 9, no. 10, pp. 756-761, 2019.

[9] J. X. Liu, "Construction and analysis of educational technology course knowledge network based on complex network," M.S. thesis, Yunnan Normal University, China, 2019. 
[10] M. B. Zhang, "Analysis of automation discipline knowledge network based on complex network," M. S. thesis, Taiyuan University of Technology, Taiyuan, China, 2015.

[11] W. J. Huang, L. G. Cai, Y. J. Hu et al., "Process planning optimization based on genetic algorithm and topological sort algorithm for digraph," Computer Integrated Manufacturing Systems, vol. 9, no. 15, pp. 1770-1778, 2009.

[12] N. Gu, L. X. Zhang, and T. Y. Xiao, "Research of assenbly sequence planning of toplological sort of directed graph on reasoning and the optimization," Journal of Mechanical Engineering, vol. 38, no. 12, pp. $142-145,2002$

Copyright $\odot 2020$ by the authors. This is an open access article distributed under the Creative Commons Attribution License which permits unrestricted use, distribution, and reproduction in any medium, provided the original work is properly cited (CC BY 4.0).

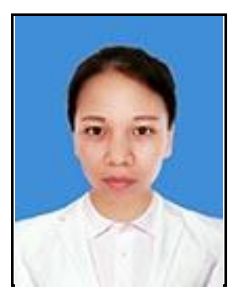

Jingxia Liu was born on June 21, 1991 in Heze, Shandong Province, China. She graduated from Yunnan Normal University with a master of science. She is now with School of Information Science and Technology,Yunnan Normal University, Kunming, Yunnan Province, China. Her major field of study is educational resources.

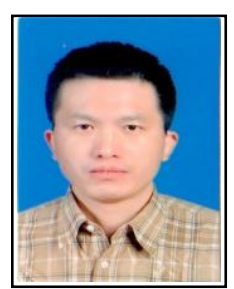

Bin Wen is working in School of Information Science and Technology, Yunnan Normal University, Kunming, China. His current research interests include intelligent information processing, emergency management, education informatization for nationalities and education resources processing. 